\title{
¿Qué condiciona los resultados de la nueva empresa tecnológica? ¿Los recursos disponibles o la estrategia escogida?
}

\author{
Antonia Mercedes García-Cabrera, María Gracia García-Soto ${ }^{1}$ Arístides Olivares-Mesa
}

Universidad de Las Palmas de Gran Canaria (ULPGC), España

doi: 10.20420/eni.2018.213

\begin{abstract}
Resumen
¿La disponibilidad de recursos humanos y sociales condiciona el rendimiento de las nuevas empresas tecnológicas? ¿Y la estrategia tecnológica elegida por el emprendedor para competir en el mercado? Este estudio encuentra que ni una ni la otra, si se consideran de forma aislada. Los resultados muestran que el rendimiento de la empresa tecnológica depende de la medida en que los recursos del emprendedor permiten ejecutar la estrategia tecnológica elegida o, en otras palabras, del ajuste entre los recursos y la estrategia. Los autores llegan a esta conclusión después de estudiar una muestra de 175 empresas tecnológicas españolas jóvenes.
\end{abstract}

Palabras clave: empresas tecnológicas, estrategia de la nueva empresa, estrategia tecnológica, estrategia pionera, resultados de la nueva empresa.

Clasificación JEL: F23, L25, L26

Agradecimientos: Los autores agradecen el apoyo financiero proporcionado por el Ministerio de Economía, Industria y Competitividad (ECO2016-80518-R).

Fuente de referencia: García-Cabrera, A.M., García-Soto, M.G., \& Olivares-Mesa, A. (2018). Entrepreneurs’ Resources, Technology Strategy, and New Technology-Based Firms' Performance. Journal of Small Business Management. doi.org/10.1111/jsbm.12411.

\section{Introducción}

La literatura sobre nuevas empresas tecnológicas (NETs) establece que los recursos humanos y sociales de los emprendedores son fundamentales, ya que les proporcionan a estas empresas capacidades distintivas que son necesarias para un buen desempeño (Colombo \& Grilli, 2010). Sin embargo, trabajos anteriores muestran que algunos de los recursos de los emprendedores, como por ejemplo la heterogeneidad de su experiencia en áreas técnicas y gerenciales, tienen una influencia positiva, mientras que otros estudios muestran que tienen un efecto negativo $\mathrm{y}$ otros no encuentran ningún efecto. Entonces deberíamos preguntarnos, ¿cuál es el verdadero efecto que las dotaciones de recursos humanos y sociales de los emprendedores ejerce sobre el desempeño de una NET?

Además, dado que las NETs son empresas de nueva creación que operan en un sector de alto nivel tecnológico, la estrategia tecnológica es uno de los factores más importantes en su desempeño (Oh, Cho \& Kim, 2015). Sin embargo, los estudios empíricos también han encontrado resultados divergentes con respecto a la influencia de esta estrategia en el rendimiento. Por ejemplo, indicadores estratégicos tales como la innovación o la búsqueda de las ventajas de ser el primero en entrar en un mercado nuevo (firstmover advantages), han mostrado efectos positivos en el rendimiento, pero también efectos negativos, o ningún efecto en absoluto. Por lo tanto, surge una nueva pregunta: ¿cuál es el

${ }^{1}$ Autor de correspondencia: gracia.garcia@ulpgc.es 
verdadero efecto de la estrategia tecnológica en el desempeño de una NET?

Para responder a estas preguntas, proponemos que se deben considerar las consecuencias de seleccionar estrategias sin tener los recursos necesarios para implementarlas $y$, en consecuencia, la necesidad de incorporar el enfoque del ajuste en estas consideraciones. En base a esto, el presente estudio tiene como objetivo explorar si el desempeño de las NETs está determinado por el grado de ajuste entre los recursos de los empresarios y las necesidades de la estrategia elegida.

\section{La estrategia tecnológica}

Existen diferentes decisiones estratégicas que un emprendedor debe tomar para guiar las acciones de las NETs, entre las cuales la estrategia tecnológica es particularmente importante. La estrategia tecnológica incluye dos opciones básicas, ser un pionero tecnológico o ser un seguidor. Los empresarios que eligen ser pioneros desarrollan una tecnología innovadora en el mercado y propia de su empresa, mientras que los seguidores adoptan estándares y mejoran los productos iniciados por los pioneros.

Ser un pionero puede tener ventajas $\mathrm{y}$ desventajas con respecto a ser un seguidor. Por ejemplo, una ventaja principal es que las ideas disruptivas proporcionan productos tecnológicamente superiores y una reputación como líder. Las desventajas de ser pioneros incluyen un mayor riesgo en términos de la funcionalidad del producto resultante o la consecuente aceptación (o no) del producto debido a la resistencia del cliente (Walsh, Kirchhoff, \& Newber 2002; Zahra, Nash \& Bickford, 1995). Por otro lado, los seguidores a veces pueden imitar rápidamente las principales características de los productos y explotarlos de manera mucho más barata que los pioneros y, por lo tanto, las ventajas de entrar el primero en el mercado puede que no sean sostenibles (Ruiz-
Ortega \& García-Villaverde, 2010). En consecuencia, podemos decir que la elección de una estrategia tecnológica adecuada, ya sea pionera o seguidora, es fundamental para la viabilidad de la nueva empresa, y esa elección debería depender de los recursos que las NETs consigan para implementar la estrategia (Park \& Bae, 2004).

En el caso de las pioneras, se requieren recursos para mantener la ventaja generada por una estrategia pionera (Boulding \& Christen, 2003). En el caso de las seguidoras, se requieren recursos para identificar las necesidades insatisfechas del mercado y la forma de satisfacer estas necesidades mediante la mejora de los productos con atributos que permiten al consumidor compararlos directamente con los ya existentes (Ruiz-Ortega \& García-Villaverde, 2010). Por lo tanto, debemos suponer que la estrategia tecnológica solo aumentará el rendimiento de la NET en los casos en que la empresa tenga los recursos necesarios para implementar la estrategia elegida (Boulding \& Christen, 2003). Debido a ello, la identificación de los recursos que los emprendedores precisan para la implementación exitosa de la estrategia tecnológica, ya sea pionera o seguidora, es fundamental para orientar las decisiones de las NETs.

\section{Los recursos de los emprendedores y el rendimiento de la empresa}

Los recursos abarcan todos los activos, capacidades, procesos y conocimientos controlados por las empresas. En el caso de las NETs, las capacidades distintivas de estas empresas se asocian con el conocimiento y las habilidades de sus fundadores (Colombo \& Grilli, 2010): las competencias tecnológicas y las capacidades gerenciales de los empresarios. Las competencias tecnológicas se refieren a la capacidad de aplicar el conocimiento científico y técnico para desarrollar productos y procesos; las capacidades gerenciales se refieren a las 
habilidades, el conocimiento y la experiencia necesarias para posicionar los productos en mercados nacionales y/o extranjeros (Colombo \& Grilli, 2010).

Además, las empresas pueden beneficiarse de su red de vínculos (recursos sociales), ya que pueden usarlos para aprender las competencias básicas de sus socios. Como las NETs se enfrentan a restricciones de recursos debido a su juventud y a tener que lidiar con entornos tecnológicos dinámicos, se pueden unir a redes empresariales para obtener la ayuda que necesitan con el objeto de implementar su estrategia. En particular, los socios de inversión y los socios tecnológicos son críticos, ya que pueden ofrecer a la empresa acceso a recursos financieros, asesoramiento, tecnología complementaria y conocimientos sobre producción, entre otras formas de apoyo (Elfring \& Hulsink, 2002).

Sin embargo, no siempre se ha encontrado este efecto positivo de los recursos humanos y sociales sobre el desempeño de las NETs. Una razón posible es que estos recursos solo tienen un valor potencial a la hora de ayudar a la empresa a implementar acciones estratégicas específicas.

\section{El ajuste entre las dotaciones de recursos de los emprendedores y la estrategia elegida}

Aunque se podría esperar que los empresarios eligieran aquellas estrategias que requieren recursos a los que tienen acceso, a menudo toman sus decisiones basándose en criterios no racionales (Zahra, Korri \& Yu, 2005). Por esta razón, los empresarios pueden elegir estrategias para las cuales carecen de recursos críticos y, por lo tanto, se enfrentan a fuertes desafíos para mantener rentables a sus empresas (Ndofor \& Priem, 2011). Como la brecha resultante entre los recursos y la estrategia puede condicionar el desempeño de la NET, el enfoque del ajuste nos puede ayudar a comprender este tipo de decisiones.
Definimos "ajuste" como la alineación entre la estrategia y los elementos internos de la empresa. Según esto, podemos esperar un rendimiento superior de las organizaciones que se parecen (se ajustan) a un perfil ideal, donde cada perfil ideal incluye una combinación de factores organizativos consistentes. Por lo tanto, sería interesante especificar perfiles ideales para la NET y demostrar que el ajuste a dicho perfil generaría un mayor rendimiento.

Para identificar tales perfiles ideales debemos considerar que, dado que las NETs operan en entornos empresariales de alta tecnología, la implementación exitosa de la estrategia tecnológica, ya sea pionera o seguidora, requiere recursos humanos y sociales relevantes (Elfring \& Hulsink, 2002). La Figura 1 muestra un mapa de posibles perfiles. Las celdas I a IV muestran las combinaciones de niveles bajos y altos de recursos humanos (capacidades gerenciales y competencias tecnológicas). En la celda IV se ubican los empresarios con mayor dotación en ambas dimensiones. Ahora bien, estos recursos se deben complementar con recursos sociales surgiendo otros perfiles más complejos que puedan garantizar el éxito de la NET. Para ello, agregamos otras dos dimensiones que permitan construir un mapa más completo: acceso a socios de inversión (que brindan apoyo financiero y gerencial) y acceso a socios tecnológicos (que ofrecen conocimiento científico y técnico). De esta forma, la combinación básica se replica cuatro veces en el cuadro ampliado, dando lugar a 16 celdas con distintas combinaciones de recursos posibles. El mapa muestra tres configuraciones ideales que potencialmente maximizarían el rendimiento de una NET: IV.2, IV.3 y IV.4. Aunque algunas empresas podrían sobrevivir con otros perfiles de la Figura 1, tales combinaciones no pueden considerarse ideales.

La celda IV.4 incluye las NETs que siguen una estrategia pionera, tratando de conseguir las ventajas del primer entrante (por ejemplo, productos superiores o reputación como líder). 
Figura 1. Tres perfiles ideales para la Empresa tecnológica estrategias pioneras) o para mejorar los productos con atributos que permitan a los

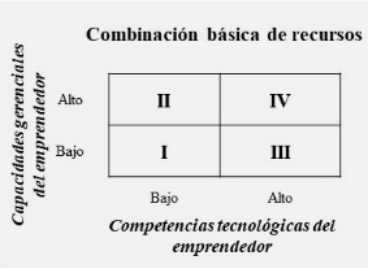

Fuente: elaboración propia

Todos los recursos parecen ser necesarios para garantizar tales ventajas (de lo contrario, la estrategia del seguidor debería ser la más adecuada). Sin embargo, no todas las combinaciones de recursos generarán un mejor rendimiento en los casos en que se implemente la estrategia de seguidor. Las celdas IV.2 y IV.3 muestran perfiles que pueden garantizar un buen rendimiento para las empresas seguidoras.

En los casos en que alguno de los recursos incluidos en una configuración o perfil ideal fallase, se podrían esperar disfuncionalidades y la estrategia tecnológica no se implementaría adecuadamente. Por ejemplo, en las configuraciones IV.2, IV.3 y IV.4, si el equipo de empresarios careciera de capacidades gerenciales o competencias tecnológicas, el ajuste disminuiría. En primer lugar, los empresarios con un mayor nivel de capacidades gerenciales, pero de mediana o baja competencia tecnológica, gozarían de una buena comprensión de las necesidades del mercado. Sin embargo, es posible que al carecer de altas competencias tecnológicas se muestren precavidos en sus decisiones. Por ejemplo, los empresarios serían conscientes de que no tienen las competencias tecnológicas necesarias para crear nuevos mercados a través de innovaciones (en el caso de consumidores compararlos con los ya existentes (en el caso de estrategias seguidoras).

De esta forma, los mayores niveles de capacidades gerenciales sin altas competencias tecnológicas podrían conducir a los empresarios que asumen el riesgo asociado a la puesta en marcha de una NET a retrasar la internacionalización de la empresa hasta que se consolide su posición en el mercado nacional. Como resultado, el rendimiento estratégico (en términos del alcance geográfico de la actividad) disminuiría y, con toda probabilidad, también disminuiría el rendimiento financiero, debido a las menores ventas asociadas al tamaño más pequeño del mercado local.

Alternativamente, en los casos en que los empresarios están técnicamente bien equipados, pero tienen una capacidad gerencial media o baja, pueden padecer de una visión demasiado optimista del potencial de mercado de sus tecnologías. Sin embargo, al carecer de un conocimiento realista del mercado, sus productos pueden enfrentarse a una demanda baja y generar un peor desempeño que en los casos en que los empresarios tienen tanto capacidad gerencial como competencia tecnológica. Esto puede suceder porque, aunque la competencia tecnológica es crítica, sin una estrategia bien concebida, hay pocas esperanzas de que la empresa pueda satisfacer rápidamente las preferencias de los consumidores en múltiples mercados nacionales e internacionales, imposibilitando el logro de un alto nivel de rendimiento.

Por lo tanto, la capacidad tecnológica y la capacidad gerencial deben estar presentes en cualquier configuración ideal para la NET. Sin 
embargo, estos recursos humanos facilitan la rentabilidad de las nuevas empresas solo cuando se combinan con un nivel adecuado de acceso a socios valiosos que brinden el apoyo requerido (Elfring \& Hulsink, 2002). En el caso de la estrategia pionera, es necesario un mayor acceso a (1) apoyo científico y técnico y (2) apoyo administrativo y financiero (configuración IV.4).

Sin embargo, en el caso de la estrategia seguidora, proponemos que uno de esos apoyos puede faltar, pero nunca ambos. Como los seguidores generalmente se basan en los estándares de la industria, su acceso a socios tecnológicos puede ser menos relevante (configuración IV.2). Sin embargo, puede suceder que otras configuraciones ideales no requieran socios inversores. Dado que las instituciones financieras como los bancos y las empresas de leasing suelen ser propensas a financiar proyectos comerciales que tienen menos riesgos (Colombo \& Grilli, 2010), un seguidor puede encontrar más fácil que un pionero obtener financiación de ellos, reduciendo así la necesidad de acceder a inversores para desarrollar proyectos altamente arriesgados. La configuración IV.3 tiene en cuenta esta circunstancia.

\section{Metodología}

\section{Medidas}

Recursos humanos. Las competencias tecnológicas y las capacidades gerenciales de los emprendedores se midieron con los siguientes indicadores: (i) Fracción de fundadores con título en Administración de Empresas o Economía; (ii) Fracción de fundadores que tienen un Master en Ciencias o Tecnología; y (iii) Fracción de fundadores que tienen experiencia laboral previa en administración de una empresa grande.

Recursos sociales. Se preguntó a los encuestados si contaron con el apoyo de: i) socios de inversión; y ii) socios tecnológicos.
Estrategia empresarial. La pregunta era: mi empresa utiliza una tecnología innovadora en el mercado, desarrollada por la empresa y comercializada por ella misma. Se pidió a los encuestados que clasificaran la estrategia como pionera cuando se cumplieran estas tres condiciones. Si al menos una de estas tres condiciones no se cumplía, los encuestados tuvieron que clasificar sus NETs como seguidoras.

Rendimiento. Los resultados de las NETs se miden por: las ganancias (beneficios antes de impuestos), el desempeño genérico y doméstico (crecimiento de las ventas en el mercado interno, crecimiento de la cuota de mercado, satisfacción del cliente, éxito de la empresa y crecimiento esperado) y el desempeño en el mercado exterior (crecimiento de las ventas en los mercados extranjeros, aumento en el número de mercados extranjeros).

Ajuste. La variable de ajuste para cada empresa se calculó a partir de la desviación de la NET con respecto a cada uno de los tres perfiles ideales de la Figura 1: configuraciones IV.2, IV.3 y IV.4.

\section{Muestra}

Una empresa se considera una NET cuando: tiene menos de 250 empleados; tiene menos de seis años de antigüedad; no está integrada en un grupo corporativo; y opera en un sector de alta tecnología, siguiendo la clasificación de sectores tecnológicos de la OCDE (2001). Según esto, la muestra consistió en 175 NETs españolas que se identificaron a partir de la base de datos SABI en 2008.

El empresario promedio en nuestra muestra tenía 40 años. Con respecto al género, el 87,7 por ciento es varón. El 67,9 por ciento de los participantes tiene una Licenciatura en Administración de Empresas o Economía, y otro 2,5 por ciento un Master en Ciencias o 
Tecnología. El 85,5 por ciento de las empresas opera en sectores de servicios de alta tecnología, mientras que el 14,5 por ciento opera en sectores manufactureros de alta tecnología. Con respecto a los recursos sociales, el 15,0 por ciento de las empresas tienen acceso a socios financieros y el 23,0 por ciento a socios tecnológicos. Además, el 36,7 por ciento de las NETs tienen alguna actividad internacional, mientras que el 28.6 por ciento sigue la estrategia pionera.

\section{Resultados}

En primer lugar, los resultados muestran que los empresarios pueden elegir estrategias para las cuales carecen de recursos críticos, lo que puede acarrearles problemas para tener éxito en la implementación de dichas estrategias. Estos resultados sugieren la relevancia que para los emprendedores tiene la intuición en su proceso de toma de decisiones.

Con respecto a los tres perfiles ideales (IV.4, IV.3 y IV.2, respectivamente) y refiriéndose al desempeño en el mercado exterior, los resultados muestran que el ajuste al perfil es relevante. Esto implica que las empresas con un alto nivel de recursos humanos y sociales que implementan una estrategia pionera (en otras palabras, NETs que se ajustan a la configuración teóricamente definida como IV.4) lograrán un mayor nivel de rendimiento. También ocurre en el caso de la configuración IV.3 que involucra la estrategia seguidora. Significa que las NETs con un alto nivel de recursos humanos en el equipo empresarial y con acceso a socios tecnológicos, aunque tengan un bajo acceso a socios de inversión, también alcanzarán un nivel más alto de desempeño en el mercado exterior. Sin embargo, no encontramos un efecto significativo del ajuste en el rendimiento del mercado exterior en el caso de la configuración IV.2.

Además, los resultados indican que los beneficios son más altos en las empresas alineadas (esto es, aquellas que se ajustan a los perfiles teóricos definidos) que en las no alineadas, cualquiera que sea la configuración ideal considerada (Figura 2).

Figura 2. Diferencias de beneficios entre las empresas alineadas y no alineadas para los perfiles ideales

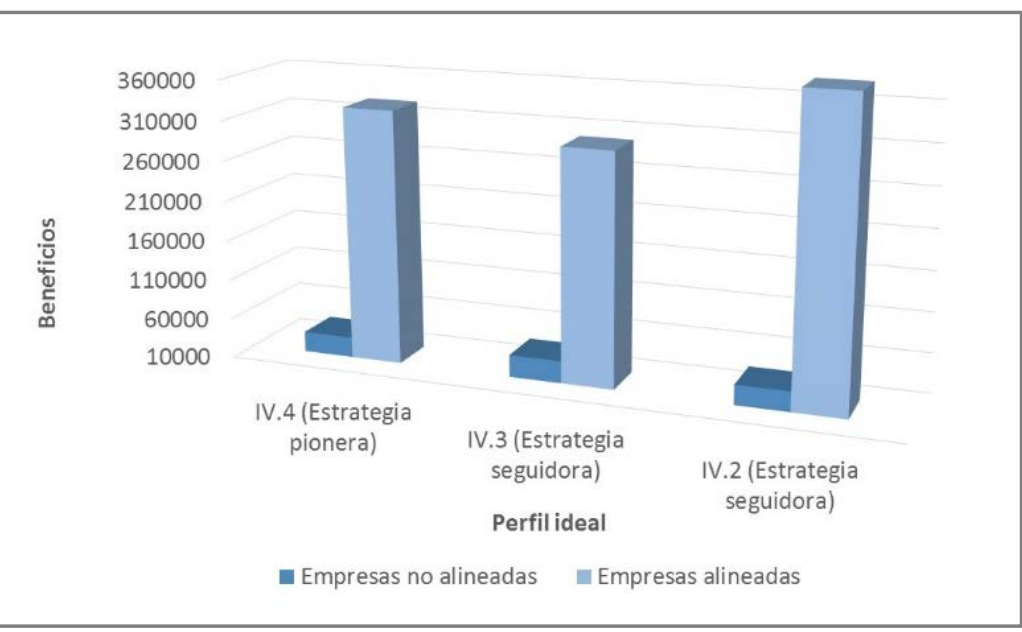

Fuente: elaboración propia

También encontramos evidencia de una diferencia significativa en el desempeño genérico y doméstico entre empresas alineadas y no alineadas para configuraciones en las que está involucrada la estrategia seguidora, con las NETs alineadas demostrando un mayor nivel de desempeño (Figura 3).

\section{Figura 3. Diferencias en el desempeño genérico y doméstico entre empresas alineadas y no alineadas para los perfiles ideales}

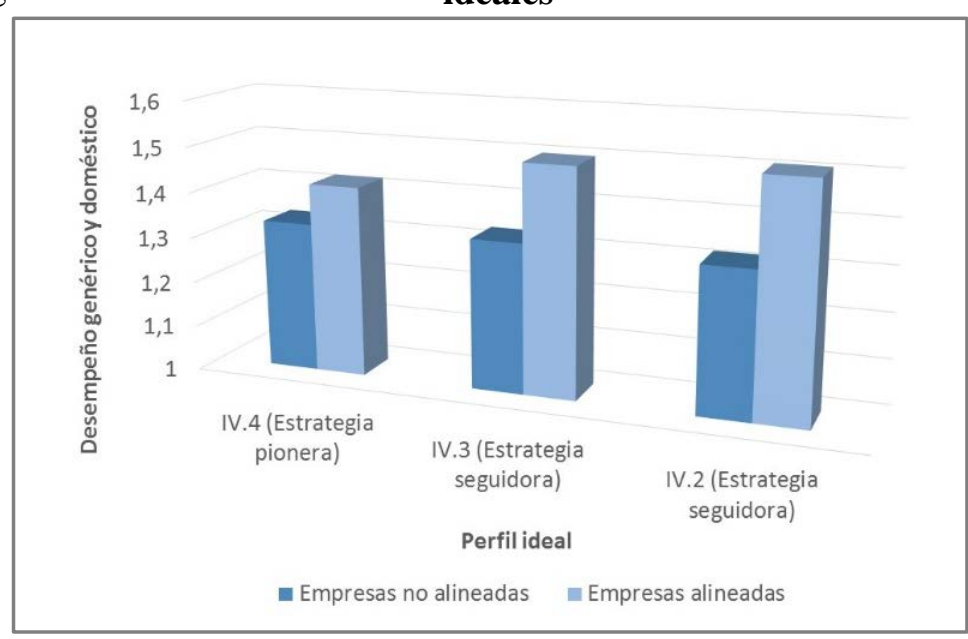

Fuente: elaboración propia 


\section{Conclusiones}

Nuestros hallazgos sugieren la necesidad de identificar el conjunto de recursos humanos y sociales específicos que deben estar bajo el control de los empresarios para la implementación exitosa de una estrategia tecnológica dada, y así afectar positivamente al desempeño estratégico y financiero de la NET. De lo contrario, aunque tener una posición sólida en términos de recursos humanos y sociales pueda apoyar el funcionamiento de la empresa, si estos recursos no están específicamente asociados con los requerimientos de la estrategia escogida, seguramente no será suficiente para garantizar un buen desempeño de la empresa.

Estos hallazgos son muy relevantes para las NETs, ya que los empresarios tienden a buscar oportunidades sin considerar los recursos que realmente controlan. En el caso de la estrategia pionera, nuestros hallazgos sugieren que el equipo emprendedor debería asegurarse de contar con altos niveles disponibles de al menos los siguientes recursos: conocimiento de administración de empresas, conocimiento sobre tecnología, experiencia en grandes empresas y acceso a socios tecnológicos e inversores, todos ellos incluidos en la variable de ajuste analizada. En el caso de la estrategia seguidora, los resultados sugieren que los empresarios deben tener los mismos recursos que los pioneros, con la excepción del acceso a socios de inversión, que puede ser bajo.

Además, si alguno de los recursos requeridos antes mencionados falta o es débil, la estrategia tecnológica no garantizará un desempeño superior en los mercados extranjeros. Por otra parte, el desempeño genérico y doméstico podría mejorarse con dos combinaciones de recursos asociados a la estrategia seguidora, mientras que el desempeño financiero se mejoraría mediante las tres configuraciones teóricas identificadas en este trabajo.

\section{Referencias}

Boulding, W., \& Christen, M. (2003). Sustainable pioneering advantage? Profit implications of market entry. Marketing Science, 22(3), 371-392.

Colombo, M.G., \& Grilli, L. (2010). On growth drivers of high-tech start-ups: Exploring the role of founders' human capital and venture capital. Journal of Business Venturing, 25, 610-626.

Elfring, T., \& Hulsink, W. (2002). Networks in Entrepreneurship: The case of high-technology firms. Small Business Economics, 21, 409-422.

Ndofor, H.A., \& Priem, R.L. (2011). Immigrant entrepreneurs, the ethnic enclave strategy and venture performance. Journal of Management, 37, 790-818.

OECD (2001). OECD science, technology and industry scoreboard 2001. Towards a knowledgebased economy, «http://www.oecd-ilibrary.org». Accessed on Feb., 2008.

Oh, C., Cho, Y. \& Kim, W. (2015). The effect of a firm's strategic innovation decisions on its market performance. Technology Analysis \& Strategic Management, 27(1), 39-53.

Park, S., \& Bae, Z-T. (2004). New venture strategies in a developing country: Identifying a typology and examining growth patterns through case studies. Journal of Business Venturing, 19, 81-105.

Ruiz-Ortega, M.J., \& García-Villaverde, P.M. (2010). Technology-oriented new ventures and entry timing. International Journal of Technology Management, 52(1/2), 46-68.

Walsh, S.T., Kirchhoff, B.A. \& Newber, S. (2002). Differentiating market strategies for disruptive technology. IEEE Transactions on Engineering Management, 49(4), 341-351.

Zahra, S.A., Korri, J.S., \& Yu, J. (2005). Cognition and international entrepreneurship: implications for research on international opportunity recognition and exploitation. International Business Review, 14(2), 129-146.

Zahra, S.A., Nash, S. \& Bickford, D.J. (1995). Transforming technological pioneering into competitive advantage. The Academy of Management Executive (1993-2005), 9(1), 17-31. 


\title{
What condition the new technology-based firms' performance? Entrepreneurs’ resources or the chosen strategy?
}

\author{
Antonia Mercedes García-Cabrera, María Gracia García-Soto ${ }^{1}$, Arístides Olivares-Mesa \\ Universidad de Las Palmas de Gran Canaria (ULPGC), Spain
}

\begin{abstract}
Does the availability of human and social resources condition a new technology-based venture's performance? And the technology strategy chosen by the entrepreneur to compete in the market place? This study found out that neither one nor the other, if they are considered in isolation. Results show that the technology-based venture's performance depends on how well the entrepreneur's resources allow the chosen technology strategy to be executed, in other words, the fit between the resources and the strategy. The authors reach this conclusion after studying a sample of 175 Spanish new technology-based ventures.
\end{abstract}

Keywords: Technology-based firms (TBFs), new venture strategy, technology strategy, pioneer strategy, new venture performance.

JEL classification: F23, L25, L26

Acknowledgements: Financial support from the Spanish Ministry of Economy and Competitiveness (ECO2016-80518-R) is gratefully acknowledged.

Reference source: García-Cabrera, A.M., García-Soto, M.G., \& Olivares-Mesa, A. (2018). Entrepreneurs’ Resources, Technology Strategy, and New Technology

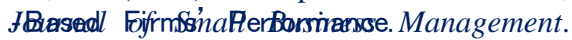
doi.org/10.1111/jsbm.12411.

\section{Introduction}

Literature on new technology-based firms (NTBFs) states that entrepreneurs' human and social resources are critical for NTBFs, as they provide these firms with distinctive capabilities that are needed for good performance (Colombo \& Grilli, 2010). However, previous works show that some of the entrepreneurs' resources - e.g., heterogeneity of experience in technical and managerial areas - have a positive influence, whereas other studies show that they have a negative effect, and yet others show no effect at all. So, it should be asked, what is the effect of entrepreneurs' human and social resources endowments on a NTBF's performance?

In addition, as NTBFs are new start-up businesses that operate in a high-tech industry, the technology strategy is one of the most important factors in their performance (Oh, Cho, \& Kim, 2015). However, empirical studies have also found divergent results with respect to the influence of this strategy on performance. For example, indicators of the strategy, such as the innovation or the search for first-mover advantages, have shown positive effects on the performance, but also negative effects, as well as no effect at all. Therefore, a new question arises: what is the effect of the technology strategy on a NTBF's performance?

To answer these questions, we propose that the consequence of selecting strategies without having the required resources to implement them must be considered, and accordingly, the need to incorporate the fit approach into the thinking. On the basis of it, the current study aim at exploring whether the NTBF's performance is determined by the degree of fit between entrepreneurs' resources and the needs of the chosen technology strategy.

${ }^{1}$ Corresponding author: gracia.garcia@ulpgc.es 


\section{The technology strategy}

There are different strategic decisions that an entrepreneur must make in order to guide the NTBF's actions, among which the technology strategy is particularly important. The technology strategy clarifies the company's choices on being a technological pioneer or a follower. Entrepreneurs that choose to be pioneers develop a technology that is innovative in the market and used by their firm, while followers adopt standards and improve products initiated by pioneers.

Being a pioneer may have advantages and disadvantages with respect to being a follower. For example, a main advantage is that disruptive ideas provide technologically superior products and a reputation as a leader. The disadvantages of pioneering include a higher risk in terms of the functionality of the resultant product or timely acceptance because of customer resistance (Walsh, Kirchhoff, \& Newber, 2002; Zahra, Nash, \& Bickford, 1995). On the other hand, followers can sometimes quickly imitate the main characteristics of products and exploit them much more cheaply than the pioneers, and hence the NTBF's first-mover advantages may not be sustainable (Ruiz-Ortega \& GarcíaVillaverde, 2010). Accordingly, we can say that the choice of a suitable technology strategy, either pioneer or follower, is critical for the viability of the new venture, and that choice should depend of the resources NTBFs marshal in order to implement the strategy (Park \& Bae, 2004).

In the case of pioneers, NTBFs require resources to sustain the advantage generated by a pioneer strategy (Boulding \& Christen, 2003). In the case of followers, they such ventures require resources to identify unsatisfied market needs and the way to meet these needs through making improvements in incumbents' products with attributes that allow the consumer to compare them directly with those already existing (Ruiz-Ortega \& García-Villaverde, 2010). Hence, we should assume that the technology strategy will only increase the NTBF's performance in cases where the firm has the requisite resources to implement the chosen strategy (Boulding \& Christen 2003). Therefore, the identification of the entrepreneurs' resources that enable the successful implementation of the technology strategy, either pioneer or follower, is critical in order to orientate NTBFs' decisions.

\section{Entrepreneurs' resources and venture performance}

Resources encompass all assets, capabilities, processes, and knowledge controlled by firms. In the case of NTBFs, the distinctive capabilities of these ventures are associated with the knowledge and skills of their founders (Colombo \& Grilli, 2010): the entrepreneurs' technological competencies and managerial capabilities. Technological competencies refer to the ability to apply scientific and technical knowledge in order to develop products and processes; managerial capabilities refer to the skills, knowledge, and experience to position the products offered in domestic and/or foreign markets (Colombo \& Grilli, 2010).

In addition, ventures can benefit from network ties (social resources), since they can use them to learn core competences from partners. Given that NTBFs face resource constraints because of their liability of newness and deal with dynamic technological environments, entrepreneurs need to join business networks from which they can obtain the help they need to implement the technology strategy. In particular, investment and technology partners are critical since these partners may offer the start-up further access to financial resources, advice, complementary technology, and production know-how, among other forms of support (Elfring \& Hulsink, 2002). 
However, positive effect of human and social resources on the NTBF's performance has not always been found. A potential reason is that human and social resources only have potential value in helping the firm to implement strategic actions

\section{The fit between entrepreneurs' resource endowments and the chosen strategy}

Although it would be expected that entrepreneurs should choose those strategies requiring resources to which they have access, they often make their decisions based on both rational and non-rational criteria (Zahra, Korri, \& Yu, 2005). For this reason, entrepreneurs might choose strategies for which they lack critical resources and hence face strong challenges in keeping their ventures profitable (Ndofor \& Priem, 2011). As the resulting gap between resources and strategy may condition the NTBF's performance, the fit approach might help to understand the NTBF's performance.

Fit is the alignment between strategy and the internal elements of the firm. According to it, we can assume superior performance for organisations that resemble an ideal profile, where each ideal profile includes a combination of organisational factors that have consistency. Thus, it is of interest to specify ideals profiles for the NTBF and to demonstrate that adherence to such a profile generate increased performance.

In order to identify such ideal profiles we must consider that, because NTBFs operate in high-tech entrepreneurial environments, the successful implementation of the technology strategy, either pioneer or follower, requires relevant human and social resources (Elfring \& Hulsink, 2002). Figure 1 shows a map of possible NTBFs' profiles. Four cells (I to IV) show the combinations of low and high levels of human resources, with entrepreneurs nurtured more fully with such resources located in cell IV. However, these resources must be complemented with social resources to shape configurations able to guarantee NTBFs success. Therefore, two other dimensions are added to build a more comprehensive map: access to investment partners that provide financial and managerial support and technology partners that offer scientific and technical knowledge. Hence, the basic combination is replicated four times in the extended chart, with 16 cells with possible combinations of resources emerging. The map shows three ideal configurations that potentially maximise NTBFs' performances: IV.2, IV.3 and IV.4. Although some ventures could survive with other profiles in Figure 1, such combinations cannot be considered ideal.

Figure 1. Three Ideal Profiles for NTBFs

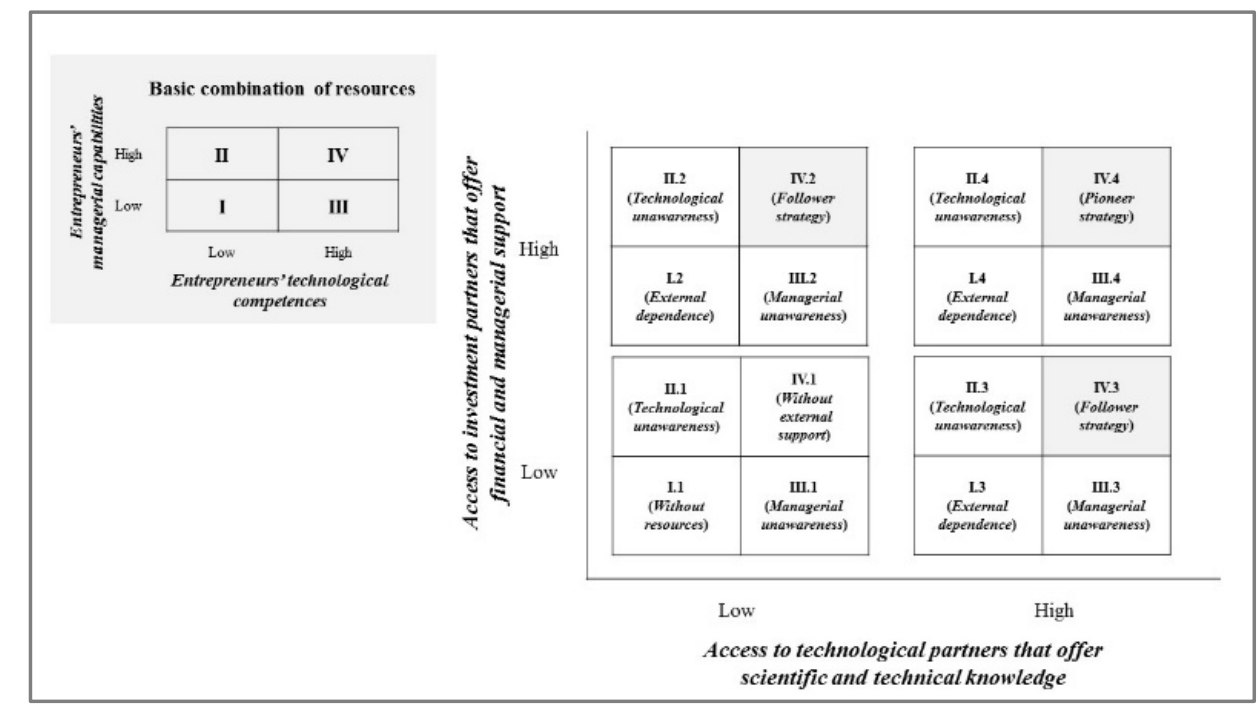

Source: The authors

Cell IV.4 includes NTBFs that follow a pioneer strategy, looking to pursue first-mover advantages (e.g., superior products, reputation as a leader). All resources seem to be necessary to guarantee such advantages -otherwise the follower strategy should be most appropriate-. However, not all combinations of resources will generate a better performance in cases where the 
technology follower strategy is implemented. Cells IV.2 and IV.3 show configurations that can guarantee performance.

In cases where any of the resources included within an ideal configuration fail, dysfunctionalities can be expected and the technology strategy will not be appropriately implemented. For example, in configurations IV.2, IV.3 and IV.4, if the team of entrepreneurs lacks either managerial capabilities or technological competencies, the fit will decline. First, entrepreneurs with a greater level of managerial capabilities - but medium or low technological competence - will have a good understanding of market needs. However, if they do not have the high technological competences necessary to create huge new markets through breakthrough innovations -in the case of pioneer strategie - or to improve existing incumbents' products with attributes that allow consumers to compare them with those already existing -in the case of follower strategies-, caution can emerge. Thus, greater levels of managerial capabilities could guide the entrepreneurs who take on the great risk associated with a NTBF to delay the venture's internationalisation until its position in the domestic market is consolidated. As a result, strategic performance -in terms of the geographic scope of activity- will decline and, in all likelihood, with it, financial performance, due to the lower sales associated with the smaller size of the local market.

Alternatively, in cases where entrepreneurs are technically well equipped - but medium or low in managerial capability - they may have an overly optimistic view of the market potential of their technologies. However, if they lack realistic knowledge of the market, their pioneer or follower products may face low demand and generate a worse performance than in cases where entrepreneurs have both managerial capability and technological competence. This may be the case because although the technological competence is critical, without a well-conceived strategy there is little hope for the firm being able to rapidly develop consumers' preferences in multiple domestic and international markets, consequently negating the attainment of a high level of performance.

Therefore, technological competence and managerial capability must be present in any ideal configuration for NTBFs. However, these human resources facilitate new ventures profitability only in conjunction with an adequate level of access to valuable partners that provide the required support (Elfring \& Hulsink, 2002). In the case of the pioneer strategy, greater access to (1) scientific and technical support and (2) managerial and financial support is necessary (configuration IV.4).

However, in the case of the follower strategy, we propose that one of them can be missing, but never both. As followers usually base themselves on industry standards, their access to technological partners may be less relevant (configuration IV.2). Yet other ideal configurations may not require investment partners. As financial institutions such as banks and leasing companies are usually prone to financing business projects that have less risk (Colombo \& Grilli, 2010), a follower may find it easier than a pioneer to obtain funding from them, so reducing the need to access investment partners to develop highly risky projects. Configuration IV.3 takes into account this circumstance.

\section{Methodology}

\section{Measures}

Human Resources. The entrepreneurs' technological competencies and managerial capabilities were operationalised with the following indicators: (i) Fraction of founders that have a Degree in Business Administration or economics; (ii) Fraction of founders that have a Master in Science or Technology; and (iii) 
Fraction of founders that have previous work experience in management in a large firm.

Social Resources. Respondents were asked about the their access to support from: i) investment partners; and ii) technology partners.

Venture strategy. The question was: My firm uses a technology that is innovative in the market, was developed by the firm and is commercialised by it. Respondents were asked to classify the venture strategy as a pioneer strategy when these three conditions were satisfied. If at least one of these three conditions were not met, respondents had to classify their NTBFs as followers.

Performance. We measure the NTBFs' results in this study by: the profits (earnings before taxes), generic and domestic performance (sales growth in domestic market, market share growth, customer satisfaction, success of the venture, and expected growth) and foreign market performance (sales growth in foreign markets, increase in number of foreign markets)

Fit. The fit variable for each venture was calculated from the NTBF's deviation from each of the three ideal profiles in Figure 1: configurations IV.2, IV.3 and IV.4.

\section{Sample}

A business venture is regarded as a NTBF when: it has fewer than 250 employees; is less than six years old; is not integrated into a corporate group; and operates in a hightechnology sector, following the OECD's (2001) classification of industries based on technology. According to it, the sample consisted of 175 Spanish NTBFs that were identified from the SABI database in 2008.

The average entrepreneur in our sample was 40 years old. Concerning gender, 87.7 percent is male. 67.9 percent of participants has a Degree in Business Administration or Economics, and another 2.5 percent a Master in Science or Technology. 85.5 percent of the ventures operate in high-technology service sectors, whereas 14.5 percent operate in high-technology manufacturing sectors. With regard to social resources, 15.0 percent of the ventures have access to financial partners and 23.0 percent of the firms to technological partners. Interestingly, 36.7 percent of the NTBFs have some international activity, while 28.6 percent follow the technology pioneer strategy.

\section{Results}

First, results show that entrepreneurs may choose strategies for which they lack critical resources, so facing problems in being successful in implementing such strategies. These results suggest the relevance that for entrepreneurs have intuition in the decision-making process.

With respect to the three ideal profiles (IV.4, IV.3 and IV.2, respectively) and referring to foreign market performance, results show that the fit variable is significant. It implies that firms with a high level of all the human and social resources and implementing a pioneer strategy (in other words, NTBFs that fit to the theoretically defined configuration IV.4) will achieve a higher level of performance. It also happens in the case of configuration IV.3 that involves the follower strategy. It means that NTBFs with a high level of all the human resources in the entrepreneurial team and access to technology partners, although having low access to investment partners, will also reach a higher level of foreign market performance. However, we did not find a significant effect for fit increasing foreign market performance in the case of configuration IV.2.

In addition, results indicate that the profits are higher in the aligned firms than in the nonaligned ones, whatever the ideal configuration considered (Figure 2). 
We also found evidence of a significant difference in generic and domestic performance between aligned and non-aligned firms for configurations where the follower strategy is involved, with the aligned NTBFs demonstrating a higher level of performance (Figure 3).

Figure 2. Comparing profits between aligned and non-aligned firms for ideal configurations

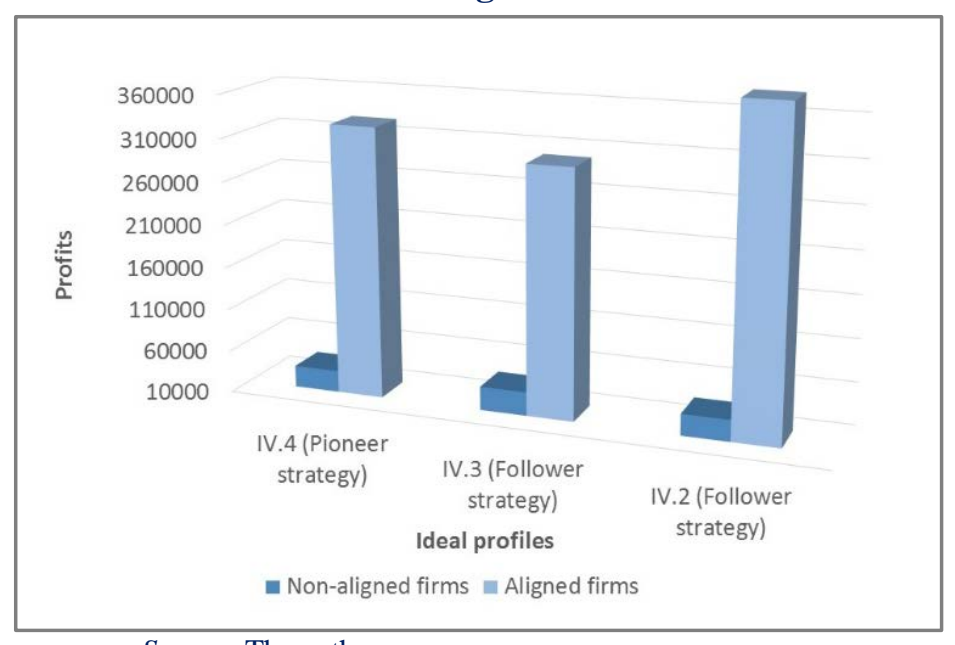

Source: The authors

Figure 3. Comparing generic and domestic performance between aligned and non-aligned firms for ideal configurations

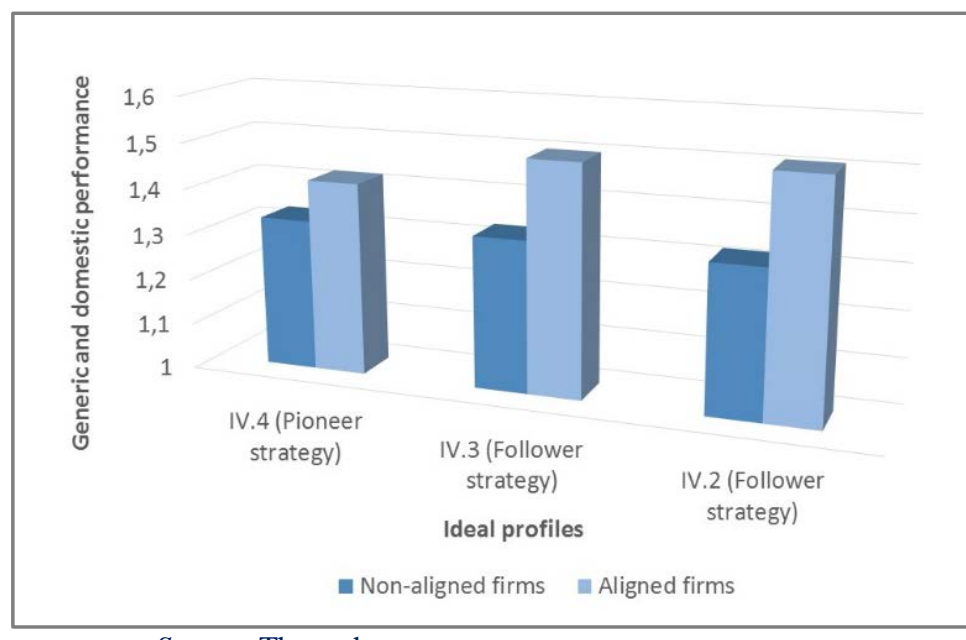

Source: The authors

\section{Conclusions}

Our findings suggest the need to identify the set of specific human and social resources that must be under the control of entrepreneurs for a successful implementation of a given strategy, and so positively affect the NTBF's strategic and financial performance. Otherwise, although having a strong position in terms of human and social resources not specifically associated with a given strategy can surely nurture the firm, this will not be enough to guarantee a good performance when implementing such a strategy.

This contribution is quite relevant for NTBFs, as entrepreneurs tend to pursue opportunities without considering the resources they actually control. In the case of the technology pioneer strategy, our findings suggest that the entrepreneurial team must have high levels of at least the following resources to hand: knowledge of business administration, knowledge about technology, experience in large firms, and access to technology and investment partners, all of them included in the fit variable. In the case of the technology follower strategy, results suggest that entrepreneurs must have to hand the same resources as pioneers with the exception of access to investment partners, which can be low.

In addition, our findings indicate that if any of the aforementioned required resources are missing or weak, the technology strategy will not guarantee superior performance in foreign markets. Furthermore, generic and domestic performance might be enhanced by two different profiles of resources-technology follower strategy, and financial performance by all three theoretical configurations identified in this work.

\section{Referencies}

Boulding, W., \& Christen, M. (2003). Sustainable pioneering advantage? Profit implications of market entry. Marketing Science, 22(3), 371-392.

Colombo, M.G., \& Grilli, L. (2010). On growth drivers of high-tech start-ups: Exploring the role of founders' human capital and venture capital. Journal of Business Venturing, 25, 610-626. 
Elfring, T., \& Hulsink, W. (2002). Networks in Entrepreneurship: The case of high-technology firms. Small Business Economics, 21, 409-422.

Ndofor, H.A., \& Priem, R.L. (2011). Immigrant entrepreneurs, the ethnic enclave strategy and venture performance. Journal of Management, 37, 790-818.

OECD (2001). OECD science, technology and industry scoreboard 2001. Towards a knowledgebased economy, «http://www.oecd-ilibrary.org». Accessed on Feb., 2008.

Oh, C., Cho, Y. \& Kim, W. (2015). The effect of a firm's strategic innovation decisions on its market performance. Technology Analysis \& Strategic Management, 27(1), 39-53.

Park, S., \& Bae, Z-T. (2004). New venture strategies in a developing country: Identifying a typology and examining growth patterns through case studies. Journal of Business Venturing, 19, 81-105.
Ruiz-Ortega, M.J., \& García-Villaverde, P.M. (2010). Technology-oriented new ventures and entry timing. International Journal of Technology Management, 52(1/2), 46-68.

Walsh, S.T., Kirchhoff, B.A. \& Newber, S. (2002). Differentiating market strategies for disruptive technology. IEEE Transactions on Engineering Management, 49(4), 341-351.

Zahra, S. A., Korri, J. S., \& Yu, J. (2005). Cognition and international entrepreneurship: implications for research on international opportunity recognition and exploitation. International Business Review, 14(2), 129-146.

Zahra, S.A., Nash, S. \& Bickford, D.J. (1995). Transforming technological pioneering into competitive advantage. The Academy of Management Executive (1993-2005), 9(1), 17-31. 